\title{
Evidence-based review of the surgical management of vertebral column metastatic disease
}

\author{
Timothy C. Ryken, M.D., Kurt M. Eichholz, M.D., Peter C. Gerszten, M.D., M.P.H., \\ William C. Welch, M.D., ZiYa L. Gokaslan, M.D., and Daniel K. ReSnick, M.D. \\ Department of Neurosurgery, University of Iowa Hospitals and Clinics, Iowa City, Iowa; Departments \\ of Neurological Surgery and Orthopaedic Surgery, and the School of Rehabilitative Sciences, \\ University of Pittsburgh Medical Center-Health System, Presbyterian University Hospital, Pittsburgh, \\ Pennsylvania; Department of Neurological Surgery, Johns Hopkins University, Baltimore, Maryland; \\ and Department of Neurological Surgery, University of Wisconsin-Madison, Madison, Wisconsin
}

\begin{abstract}
Object. Significant controversy exists over the most appropriate treatment for patients with metastatic disease of the vertebral column. Treatment options include surgical intervention, radiotherapy, or a combination of the two; nevertheless, a standard of care that yields the best survival, outcome, and quality of life has not been established. The purpose of this review was to determine the foundation in the literature of views favoring surgical intervention for spinal metastatic disease.

Methods. A search of the English-language literature published between 1964 and 2003 was performed for the subject of spinal metastatic disease. Papers were selected based on the inclusion criteria described, and evidentiary information was compiled and graded using previously described methods.

Conclusions. Although there is insufficient evidence to support a standard for surgical treatment in patients with metastatic spinal disease, the authors present guidelines and recommendations based on the evidence provided by the current literature.
\end{abstract}

\section{KEY WORDS - spinal cord compression - cancer - metastasis • radiation therapy • evidence-based medicine}

The spinal column is the most frequent site of bone metastasis. ${ }^{1,44}$ Metastatic spinal disease is a significant problem for a large number of patients: spinal metastases develop in between 5 and $10 \%$ of all patients with cancer during the course of their disease. ${ }^{7}$ Approximately $40 \%$ of persons dying of cancer have autopsy evidence of spinal metastases; $;, 7,2810 \%$ of these will experience spinal cord compression with subsequent neurological deficits. ${ }^{47,55}$ The annual incidence of spinal cord compression due to spinal metastases is estimated to be 20,000 cases. ${ }^{16}$ In recent autopsy studies, investigators found metastatic involvement of the spine in $90 \%$ of patients with prostate carcinoma, in $75 \%$ of those with breast carcinoma, $55 \%$ of those with melanoma, $45 \%$ of those with lung carcinoma, and $30 \%$ of those with renal carcinoma. ${ }^{32,56,67}$ Specific carcinomas cause clinically significant spinal cord compression in a higher percentage of patients. Twenty-two percent of patients with breast cancer, $15 \%$ of those with lung cancer, and $10 \%$ of those with prostate carcinomas experience symptomatic spinal cord compression. ${ }^{56}$

There is a slight preponderance of metastatic tumors in male $(60 \%)$ compared with female patients. ${ }^{15}$ This sex dif- ference may reflect the incidence of primary breast lesions compared with prostate tumors in published series. All ages of patients may be affected, but the period of highest prevalence coincides with the relatively high cancer risk period that occurs between 40 and 65 years of age. ${ }^{9}$

Metastatic spinal lesions involve the vertebral column and pedicle (85\%), the paravertebral spaces $(10-15 \%)$, or the epidural space. ${ }^{11,23}$ The junction of the vertebral body and pedicle is usually the portion of the vertebra involved with metastasis. ${ }^{11,42}$ Metastatic spread to bone may be related to osteotropism of the malignant cells, direct spread, and the highly vascular supply to bone marrow. ${ }^{1}$ Seventy percent of cases occur at the thoracic level, $20 \%$ at the lumbar region, and $10 \%$ at the cervical region..$^{23}$ Increased frequency of spinal metastases at the thoracic vertebrae may be related to the fact that there are more thoracic vertebrae than lumbar and cervical ones. Metastatic lesions present initially at multiple, noncontiguous levels in 10 to $38 \%$ of cases. ${ }^{23,39,45}$

The incidence of metastatic spinal disease is likely to increase in the future. Improvement in diagnostic capabilities, especially the widespread availability and sensitivity 
of magnetic resonance imaging, may increase the number of patients evaluated and metastatic lesions detected. Progress in many multimodality cancer treatments will prolong patient survival, resulting in more spinal metastases. Screening programs yielding earlier detection of malignant primary lesions will lead to identification of an ever-increasing number of spinal metastases.

Standard treatments for metastatic spinal tumors include radiotherapy alone, radiotherapy plus systemic chemotherapy, hormone therapy, surgical decompression followed by radiotherapy, and, more recently, extracranial radiosurgery. ${ }^{21,46}$ When a metastatic spinal tumor causes compression of the spinal cord or other neural elements, surgical decompression is often chosen. Based on the extent of spinal column destruction and the resulting biomechanical instability of the spine, fixation may be elected. The goal of local radiation therapy in the treatment of spinal metastases has been palliation of painful symptoms, prevention of pathological fractures of the vertebral body, and halting or reversing progression of neurological compromise. The role of radiosurgery has yet to be defined but will likely be limited to treatment of focal disease or use as a supplement to fractionated radiotherapy.

In this evidence-based review we will examine the basis for current clinical practice, focusing on the role of surgery in the management of metastatic spinal column disease.

\section{Rationale for the Study}

Metastatic spinal column tumors occur with sufficient frequency to warrant review. The role of surgery in the therapeutic management of vertebral column metastatic disease remains controversial. In 1998, the Canadian Task Force on the Periodic Health Examination produced an evidence-based guideline review of the literature. ${ }^{33}$ At the time, the authors concluded that very few papers of high methodological quality had been published, and that more studies were needed to verify the validity of many of the clinical decisions regarding the management of this disease process.

For this review, medical literature addressing surgical management of vertebral column metastatic lesions was examined using the methods of evidence-based medicine to address the following question: "What is the role of surgical management of vertebral column metastatic disease?"

\section{SEARCH METHODS}

The database of the National Library of Medicine was searched using the PubMed search engine. The key words "spine" and "metastasis" were used, with limiting factors of "human" and "English language." All articles dating from 1964 through August 2003 were included in the final review; this search produced 1178 articles. Titles and abstracts were then reviewed, and only articles addressing surgical management of spinal metastases were retained. Papers that primarily analyzed the nonoperative treatment of spinal metastases were excluded in the evidentiary table. The bibliographies of included papers were also examined to assess the completeness of the literature review. Additional papers identified from these bibliogra- phies that contained relevant supporting information were then included. This yielded a total of 46 articles, which are summarized in Table 1. Additionally, we were aware of an abstract presented at the $39^{\text {th }}$ Annual Meeting of the American Society of Clinical Oncology by Patchell, et al. ${ }^{40}$ Although this cannot be included in the evidentiary tables until it is published, it is noted in the Discussion and References sections.

\section{Scientific Foundation}

The annual incidence of spinal cord compression caused by spinal metastases is estimated to be 20,000 cases. ${ }^{16}$ As discussed, the incidence of metastatic spinal disease is likely to increase in the future. In one evidencebased guideline review of the literature, researchers found that current surgical recommendations are based on inconclusive evidence. ${ }^{33}$ Surgery may be considered a first-line treatment for ambulatory patients presenting with spinal instability, bone compression, or paraplegia. Our review focuses on the most significant articles identified in the literature search. The author and year of publication, a description of the study, a data class, and a conclusion is provided for each paper in Table 1.

\section{Classification of Evidence}

When assessing the value of therapies or interventions, the available data are classified into one of three categories according to the criteria established in the guidelines for the management of acute cervical spine and spinal cord injuries. ${ }^{4}$

\section{RESULTS}

Currently, there is only one Class I study available in the peer-reviewed literature. ${ }^{69}$ This study shows no significant outcome difference when comparing 16 patients who underwent laminectomy followed by radiation with 13 patients who underwent radiation alone. This study was performed in 1980, however, had a small population (29 patients), and a short mean follow-up duration (4 months). As mentioned previously, Patchell, et al., ${ }^{40}$ recently performed a prospective randomized trial in 101 patients with spinal cord compression caused by metastasis. These authors showed that patients treated with surgery followed by radiotherapy maintained continence and had functional Frankel and American Spinal Injury Association Scale scores significantly longer than patients who were treated with radiotherapy alone. Also, a significantly larger number of non-ambulatory patients in the surgery group (56\%) than in the radiotherapy group (19\%) regained the ability to walk.

Four Class II studies have been published..$^{51,55,59,62}$ In two of these studies the authors have proposed treatment algorithms. ${ }^{51,59}$ Wai and colleagues ${ }^{62}$ used the Edmonton Symptom Assessment Scale both pre- and postoperatively in 25 consecutive patients who underwent surgery for spinal metastases. This study, as well as several Class III studies, ${ }^{13,14,19,24,26,48,63,64}$ indicated an improved quality of life in patients who had undergone surgery for spinal metastases.

Several studies showed that the majority of patients who underwent surgical decompression for spinal me- 
Surgical management of vertebral column metastatic disease

TABLE 1

Literature revew of studies of surgical management of vertebral column metastatic disease

Class I

\begin{tabular}{|c|c|c|c|}
\hline Reference & Description & Results & Conclusion \\
\hline $\begin{array}{l}\text { Young,et al., } \\
1980\end{array}$ & $\begin{array}{l}\text { Rambonized prospective study of } 29 \\
\text { patients who underwen laminectomy } \\
\text { plus radiation (16 patients) versus } \\
\text { radiation alone (13 patients) }\end{array}$ & 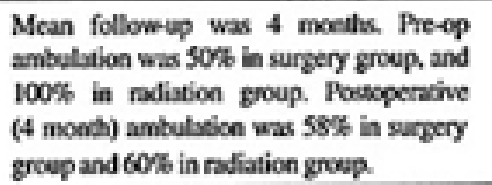 & 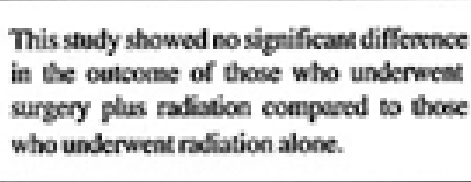 \\
\hline
\end{tabular}

Class II

\begin{tabular}{|c|c|c|c|}
\hline Reference & Description & Results & Conclusion \\
\hline $\begin{array}{l}\text { Siegal, } \\
1985\end{array}$ & $\begin{array}{l}\text { Prospective review of } 86 \text { patients with } \\
\text { spinal cord compression treated } \\
\text { surgically: } 61 \text { via corpetomy and } 25 \text { via } \\
\text { laminectomy. An algorithm fe sargical } \\
\text { indicatioes is proposed. }\end{array}$ & $\begin{array}{l}\text { Improvement in ambulation, bowel, and } \\
\text { bladder dysfunction wete seen in the } \\
\text { corpectomy group and, to a lesser degree, } \\
\text { the laminectomy growp. }\end{array}$ & $\begin{array}{l}\text { Role of surgical decompecsion as the } \\
\text { primary treatment for ventrally located } \\
\text { tumoes should be strongly sonsidered, } \\
\text { while the role of laminectoeny in } \\
\text { posterior compartment tamors is less } \\
\text { sertain. }\end{array}$ \\
\hline $\begin{array}{l}\text { Sundaresan, et al, } \\
1991\end{array}$ & $\begin{array}{l}\text { Prospective study of } 54 \text { patients } \\
\text { comparisg de novo surgical spial } \\
\text { metastasis patients to histocical controls, } \\
24 \text { ambulatory and } 30 \text { son-ambulatory }\end{array}$ & $\begin{array}{l}46 \% \text { of patients survived } 2 \text { years, } \\
37 \text { patients also netived meliation. } \\
22 \% \text { of survivors were ambulatory. } \\
90 \% \text { had pain relief. }\end{array}$ & $\begin{array}{l}\text { Major benefin of sergery peeserving } \\
\text { ambalation that persists in loeguerm } \\
\text { survival. }\end{array}$ \\
\hline $\begin{array}{l}\text { Toenita, et al., } \\
2001\end{array}$ & $\begin{array}{l}\text { Two parts: } \\
\text { Retrospective review of } 67 \text { patients and } \\
\text { seoed based oa prognostic factors. } \\
\text { Treatnent strategy was devised and } 61 \\
\text { patients were treated prospectively with } \\
\text { this paradigm. }\end{array}$ & $\begin{array}{l}\text { Mean sarvival was } 38.2 \text { moeths for } \\
28 \text { patients treated with wide or marginal } \\
\text { reseetion, } 21.5 \text { months for } 13 \text { patients } \\
\text { with intralesional exeision, } 10.1 \text { months } \\
\text { for } 11 \text { patients with palliathe surgery. } \\
\text { and } 5.3 \text { moeths for those with terminal } \\
\text { case. }\end{array}$ & $\begin{array}{l}\text { Treatment algorithm proposed based on } \\
\text { prognostic factors incloding grade of } \\
\text { malignancy. visceral metastases, and } \\
\text { bone metastases. }\end{array}$ \\
\hline $\begin{array}{l}\text { Wai,et al., } \\
2003\end{array}$ & $\begin{array}{l}\text { Prospective quality of life assessment of } \\
2 S \text { potients using Bdmonton Symptom } \\
\text { Asvessment Scale. }\end{array}$ & $\begin{array}{l}\text { Surgery showed significant improvement } \\
\text { in pain, tiredness, nausea, anxiety. } \\
\text { drowsiness, appetite, and well-being. }\end{array}$ & $\begin{array}{l}\text { Surgery improved quality of life in } \\
\text { patients with spinal metastasis. }\end{array}$ \\
\hline
\end{tabular}

\section{Class III}

\begin{tabular}{|c|c|c|c|}
\hline Reference & Description & Results & Conclusion \\
\hline $\begin{array}{l}\text { Akeyson \& } \\
\text { MeCutcheoe, } \\
1996\end{array}$ & $\begin{array}{l}\text { Retrospective neview of } 25 \text { patients who } \\
\text { enderwent postarior venctrectoniny for } \\
\text { metastatic diseace of the thoracolumbar } \\
\text { spine. }\end{array}$ & $\begin{array}{l}\text { At time of seview, } 22 \text { of } 25 \text { patients } \\
\text { had died. Mean survival after surgery } \\
\text { was } 29.5 \text { +1. } 8.2 \text { weeks. Majority had } \\
\text { impeovement in pain. } 55 \% \text { improved } \\
\text { neusologically. Functional status was } \\
\text { imperved or unchanged in all patients. } \\
76 \% \text { had no improvement in functional } \\
\text { status. }\end{array}$ & $\begin{array}{l}\text { Posterior vernebrectomy is feasible for } \\
\text { radical resection of vertebral body } \\
\text { metastases when combined with } \\
\text { reconstruction and stabillization for } \\
\text { patients in whom thoracolomy is } \\
\text { eontraindicaled. However, complication } \\
\text { rate is high. }\end{array}$ \\
\hline
\end{tabular}


T. C. Ryken, et al.

TABLE 1, continued

Literature revew of studies of surgical managenent of vertebral colunn metastatic disease

Class III, contintued

\begin{tabular}{|c|c|c|c|}
\hline Reference & Description & Results & Conclusion \\
\hline $\begin{array}{l}\text { Arbit \& Galicich, } \\
\text { I995 }\end{array}$ & $\begin{array}{l}\text { Retrospective review of } 10 \text { potients who } \\
\text { underwent anterior vertebral body } \\
\text { reseetion exing modified Harrington } \\
\text { distration syotem. }\end{array}$ & $\begin{array}{l}\text { Five patients underwent single level } \\
\text { resection, } 3 \text { had a } 2 \text { level, and } 1 \text { a } 3 \text { level. } \\
\text { Most had poin refief, but there was little } \\
\text { improvement in anbulatory function. }\end{array}$ & $\begin{array}{l}\text { Amterioe fixation is a feasible and safe } \\
\text { technique in this patient population to } \\
\text { cavere stability. Pain is impeoved, but } \\
\text { impeovensent in meurologic function is } \\
\text { limited. }\end{array}$ \\
\hline
\end{tabular}

$31 \%$ had laminectomy, $26 \%$ bod

bminoctony followed by radiokerapy.

Retrospective population cohort review and $43 \%$ had radiotherapy alone. $79 \%$ of

Bach, et al., $\quad$ over a 6 year period of 398 potients with

those who were ambelatory remained ambulatory. while cely $18 \%$ of the non. ambulatory potients regained ambulation. cancer.

Paticnts who had surgery followed by rodiotherapy had a betier response.

\begin{tabular}{l|l} 
& cancer. \\
\hline $\begin{array}{l}\text { Bilsky, st al., } \\
2001\end{array}$ & $\begin{array}{l}\text { Retrospective outcome analysis of } 59 \\
\text { patients who hal surgery for metastatic } \\
\text { sarcoma of spine. }\end{array}$ \\
\hline $\begin{array}{l}\text { Bnackman \& } \\
\text { Bloomer, }\end{array}$ & $\begin{array}{l}\text { Retrospective review of islications for } \\
\text { lamincctomy for decompecsion prior to } \\
\text { widespecad use of amerior appeoches in } \\
312 \text { patients. }\end{array}$
\end{tabular}

95\% of patients maintaincd or regained ambulatice. Modian survival was is noethr, median interval between 1 " and $2^{24}$ operations was 13 monthe.

Early diagnosis and aggressive treatment may preserve gait function in $80 \%$ of ambulatory potichts developing spinal coed compecssion.

Best prognostic indicator for rocovery of function was pre-treatment status. Of patients who were paretic preoperatively. $35 \%$ were ambalatory after sergery. Only $7 \%$ of those who weet paraplezic besame ambulatory.

\begin{tabular}{l|l} 
& $\begin{array}{l}\text { Retronpective case study of } 30 \text { potients } \\
\text { with cervical spinal vertebral neoplasms } \\
\text { who underwent anterior cervical } \\
\text { decompression asd plate stabilization } \\
\text { within a } 7 \text { year period. }\end{array}$
\end{tabular}

All bat one patiena beecficd from a significantly improved quality of life with decreased pain and/or imperoved nevorological stabus. Patients achieved long-tem statility, with only one patient requiring a repeat posicrior stabilization procedure. There was no difference in survival between patients with metautatic ncoplasms and those with bmephonatous and mowhiple myeloma ncoplasms.

\begin{tabular}{c|l}
\hline $\begin{array}{c}\text { Chataigner \& } \\
\text { Onlmux 2000 }\end{array}$ & $\begin{array}{l}\text { Retrospective review of } 107 \text { poticnts } \\
\text { who were operated on for spinal } \\
\text { metastases. }\end{array}$ \\
\hline
\end{tabular}

DeWald, et al., 1985

Retrospective review of 17 patients with metactabic malignancies who underwent anterior corpectomy, and in some cases poustior fusion.

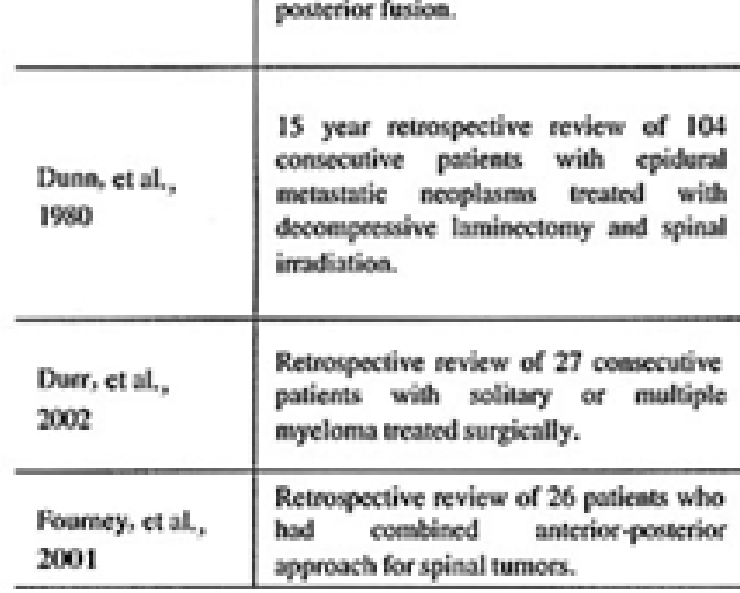

Preoperative vertebral pain in all patients, 43 had radicular complaints, 93 paticats were dead at time of review.

5 cervical, 11 thoracolumbar tumos. II of 17 patients had ingrovement in pain, S of 11 paralyzed patients had significant neural recovery. and all maintained spinal stability. 3 died within I month of surgery.

$33 \%$ bencfited from sorgery. $23 \%$ became worse, $22 \%$ of nos-ambulatory patients rezained ambulatory fonction, but $22 \%$ of ambulatory patients were unable to walk afier surgery. Tumor histology asd preoperative newrological status important prognostic factoes.

1 year after surgery. 24 patients survived and had improved from presurgieal conditioa based on Frankel, Karnofiky. and Kaplan Meier scoring system.

IS patients had primary malignant spine tamors, 11 patients had mets. $96 \%$ had improvement in pais at one month.
Surgery is useful in maintaining or improving neurological and functional oucoenes.

Early surgical interventien is indicated in patients who have mpidly progressive or severe neunologic symptoms.

Faverable clinical outeome of bock neurological symptoms and pais can be achieved with anterior cervical plate stabilization after surgery for mooplasms of the cervical venctrac. Long-term mechankeal stability is actieved evea when radiation is deliverod to the site of the bone graft.

Surgery in patients without neurological deficit increases functional stahus, but does not improve survival.

Goals of sergery should be to decrease pain, to perserve of to improve neurologie function, and to mobilixe the patient without external orthosis.

Indications for surgery inclode need for histological diagnosis, neurological deterionation, during radiotherapy. of necurreat symptoms.

Sargery for multiple myeloma is eflective in impeoving neurologic fenction and quality of life.

Combined anterior-posterior approach for recoeslaction is sofe and feasible. 
TABLE 1, continued

Literature revew of studies of surgical managenent of vertebral column metastatic disease

Class III, continzed

\begin{tabular}{|c|c|c|c|}
\hline Reference & Description & Results & Conclusion \\
\hline $\begin{array}{l}\text { Gesogawala, et al. } \\
2001\end{array}$ & $\begin{array}{l}\text { Retrospective review of } \$ 5 \text { patients with } \\
\text { symptomatic spinal cond compession } \\
\text { treated with radiation only, radiation } \\
\text { followed by sargery, or surgery followed } \\
\text { by radiation. }\end{array}$ & $\begin{array}{l}\text { Radiation prior to surgery incteased } \\
\text { wound infection from } 12 \text { to } 32 \% \text {. } \\
\text { Patients who had sargery prior to } \\
\text { radiation had superior Frankel score, and } \\
75 \% \text { remained ambulatory. }\end{array}$ & $\begin{array}{l}\text { Radiatice prior to surgery increases } \\
\text { wound complication rate and may } \\
\text { adversely affect surgical coucome. }\end{array}$ \\
\hline $\begin{array}{l}\text { Gokaslan, et al, } \\
1998\end{array}$ & $\begin{array}{l}\text { Retrospective review of outcomes of } \\
72 \text { potients with metastatic spinal bemos } \\
\text { who were treated with tranathoracic } \\
\text { vertebrectomy. } \\
\text { reconstruction with methylmethacrylase, } \\
\text { and anterior fixation. }\end{array}$ & $\begin{array}{l}\text { Posterior sopplementation was required } \\
\text { in } 7 \text { patients, } 92 \% \text { had improvement in } \\
\text { pain, } 67 \% \text { had impeovemesh of } \\
\text { neurologieal dysfunction. } 10 \text { of } 13 \\
\text { patients who were noe-anbelatory } \\
\text { pecoperatively could walk after sargery. }\end{array}$ & $\begin{array}{l}\text { Transthoracic vertebrectomy and spinal } \\
\text { stabilization can improve the quality of } \\
\text { life of cancer paticats with spinal mets } \\
\text { by preserving of restoring ambulation } \\
\text { and by controlling intractable pain. }\end{array}$ \\
\hline $\begin{array}{l}\text { Hall \& Mackay } \\
1973\end{array}$ & $\begin{array}{l}\text { Rearospective review of } 129 \text { paticass } \\
\text { endergoing baminectongy over io year } \\
\text { period for compression of spinal coed er } \\
\text { cauda equina. }\end{array}$ & $\begin{array}{l}35 \% \text { of patients who had incomplete } \\
\text { paraplegia and had immediate } \\
\text { laminectomy regained ambulation. }\end{array}$ & $\begin{array}{l}\text { Eafly diagnosis is key to impeoving } \\
\text { postoperative outcome after posterior } \\
\text { decompecsion for patients with } \\
\text { incomplete paralysis. }\end{array}$ \\
\hline $\begin{array}{l}\text { Hammerterg, } \\
1992\end{array}$ & $\begin{array}{l}\text { Retrospective review of } 56 \text { consecutive } \\
\text { patients Who underwent sargical } \\
\text { interventioa for metastatic spine disease. }\end{array}$ & $\begin{array}{l}91 \% \text { of patients had significant pain } \\
\text { improvement. } 74 \% \text { had neurologic } \\
\text { improveresent. }\end{array}$ & $\begin{array}{l}\text { Goal of surgical treatment of metastatic } \\
\text { spine disease is to ingrove the quality of } \\
\text { the remaining life, by the relief of pain } \\
\text { and preservation or restoration of } \\
\text { neurologie function. }\end{array}$ \\
\hline $\begin{array}{l}\text { Harringion, } \\
\text { 19s4 }\end{array}$ & $\begin{array}{l}\text { Retrospective analysis of } 52 \text { poticats } \\
\text { with spinal instability secondary to } \\
\text { metastatic pothological fractures who } \\
\text { anderwent anterior decompression and } \\
\text { stabilization by replacemeat with MMA. }\end{array}$ & $\begin{array}{l}40 \text { patients had major neurological } \\
\text { impairment preoperatively, and } 21 \text { had } \\
\text { complete recovery posiogerntive, 13 } \\
\text { improved significantly, and } 6 \text { remained } \\
\text { unchanged or worsened. Three cases had } \\
\text { failure of fixation. }\end{array}$ & $\begin{array}{l}\text { While this uechnigue should eot be applied } \\
\text { to all potients with spinal mets, anterior } \\
\text { decompression of lesions compressing the } \\
\text { spinal cord is usaally highly effective in } \\
\text { reversing even high grode deficits, and } \\
\text { provides immediane pain relief. }\end{array}$ \\
\hline $\begin{array}{l}\text { Hosono, et al., } \\
\text { I99s }\end{array}$ & $\begin{array}{l}\text { Retrospective review of elinical outcome } \\
\text { of } 84 \text { paticnts who underwent vertebral } \\
\text { body etplacement via anterior approoch } \\
\text { with ecramic prosthesis. }\end{array}$ & $\begin{array}{l}94 \% \text { had pain relief, } 81 \% \text { had } \\
\text { improvement in motor function, and } 64 \% \\
\text { recovered ambulation. }\end{array}$ & $\begin{array}{l}\text { Vertebral body replacement can be } \\
\text { useful after tumor resection for } \\
\text { managing pain of eeurologic deficits. }\end{array}$ \\
\hline $\begin{array}{l}\text { Jackson, et als, } \\
2001\end{array}$ & $\begin{array}{l}\text { Retrospective review of } 79 \text { patients } \\
\text { treated sargically for renal cell } \\
\text { caecinoma metastatic to the spise. }\end{array}$ & $\begin{array}{l}79 \text { patients underwent } 107 \text { spinal } \\
\text { operations, Intemal firation performed in } \\
\text { all patients. Median survival was } 12.3 \\
\text { months, with significant pain roduction } \\
\text { in } 89 \% \text {. neusological inprovement in } \\
65 \% \text {. }\end{array}$ & $\begin{array}{l}\text { In patients with renal cell caecinoma } \\
\text { metastatic to the spine, resection and } \\
\text { stabilization can provide pain relief and } \\
\text { neurological preservation or } \\
\text { impeovement. }\end{array}$ \\
\hline $\begin{array}{l}\text { Lee, et al., } \\
1986\end{array}$ & $\begin{array}{l}\text { Retrospective review of } 20 \text { potients who } \\
\text { were treated surgically using anterior } \\
\text { appreach for anterioe lesions, posterior } \\
\text { appreach for posterioe lesions, and } \\
\text { combined appeoach for extensive lesions. }\end{array}$ & $\begin{array}{l}\text { Author's grading seale rated results as } \\
\text { exoellent in } 7 \text { patients, good in } \\
6 \text { patients, aed fair in } 7 \text { potients. }\end{array}$ & $\begin{array}{l}\text { In selected patients, these guidelines } \\
\text { result in satisfactory culcomes. }\end{array}$ \\
\hline $\begin{array}{l}\text { Manabe, et al, } \\
1989\end{array}$ & $\begin{array}{l}\text { Retrospetive seview of } 25 \text { patients with } \\
\text { vertebral body involvement who } \\
\text { underwent compectomy and rooustruction. }\end{array}$ & $\begin{array}{l}75 \% \text { had excellent result from surgery. } \\
\text { All paticnts hod pain relief. Incestineace } \\
\text { resolved in } 5 \text { of } 8 \text { patients. Average } \\
\text { survival was } 8 \text { months. There was no } \\
\text { correlation between type of tumor and } \\
\text { surgleal resulh, of between surgieal } \\
\text { appeouch and eeurologie progeosis. }\end{array}$ & $\begin{array}{l}\text { Goal of sargical treatment of metaustac } \\
\text { spinal tumors should be to maintala } \\
\text { seurologic functice without pain for } \\
\text { duration of life expectancy. }\end{array}$ \\
\hline $\begin{array}{l}\text { MeDonnell, et al., } \\
1996\end{array}$ & $\begin{array}{l}\text { Retrospective review of } 19 \text { patients } \\
\text { undergoing anterior prosclares of the } \\
\text { spiene. }\end{array}$ & $\begin{array}{l}21 \% \text { had major complications, and } 16 \% \\
\text { had minor complications. Higher rate of } \\
\text { major complications was found with } \\
\text { combined anterior and posterior } \\
\text { procedures rather than with staged } \\
\text { anterior and posterior prosedures. }\end{array}$ & $\begin{array}{l}\text { Rate of major complications after } \\
\text { anterior decompression and fusion is } \\
\text { high, with most ( } 37 \% \text { ) of complications } \\
\text { velated to pulmonary issues. }\end{array}$ \\
\hline
\end{tabular}


TABLE 1, continued

Class III, continued Literature revew of studies of surgical management of vertebral column metastatic disease

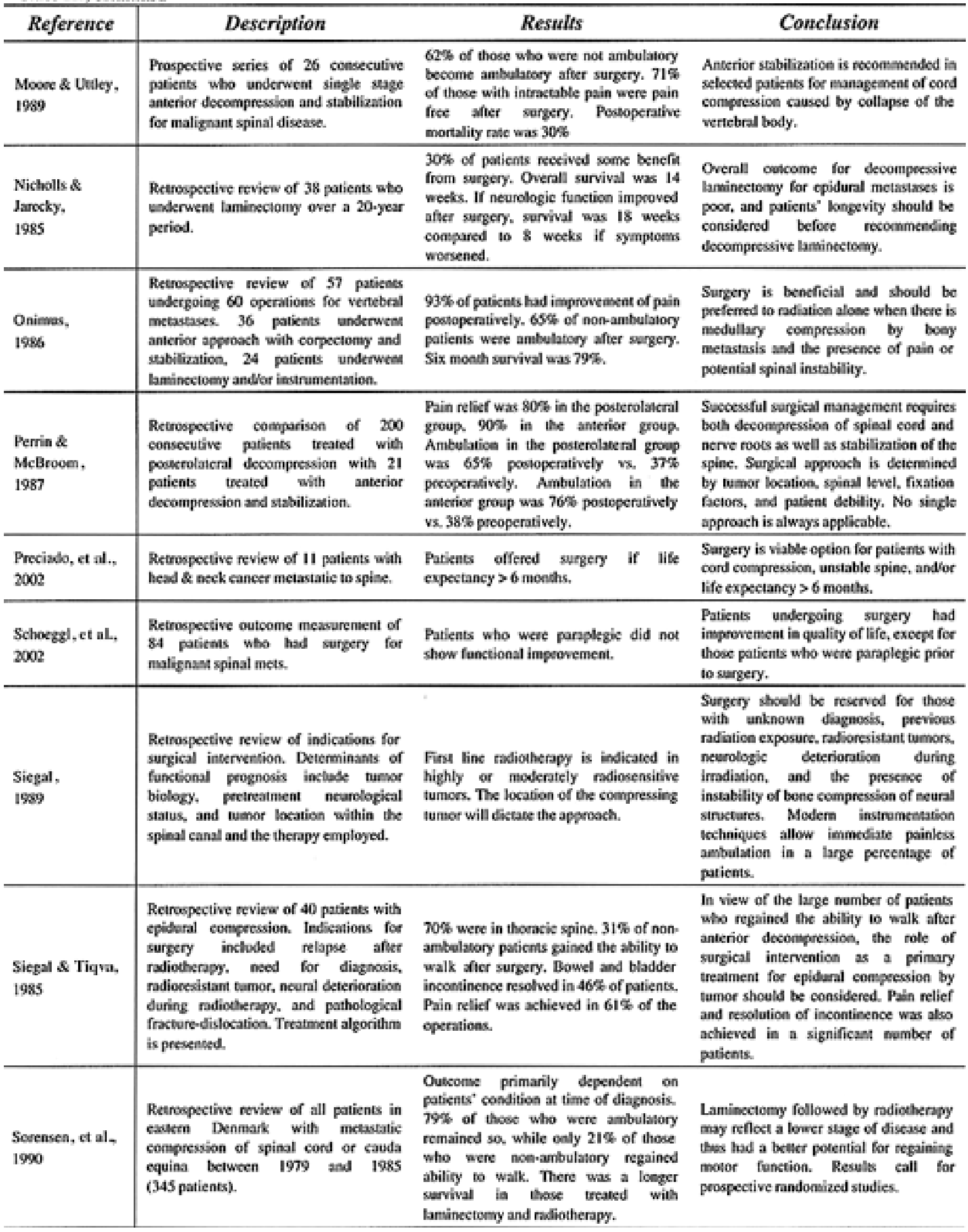


TABLE 1, continued

Literature revew of studies of surgical managenent of vertebral column metastatic disease

Class III, continued

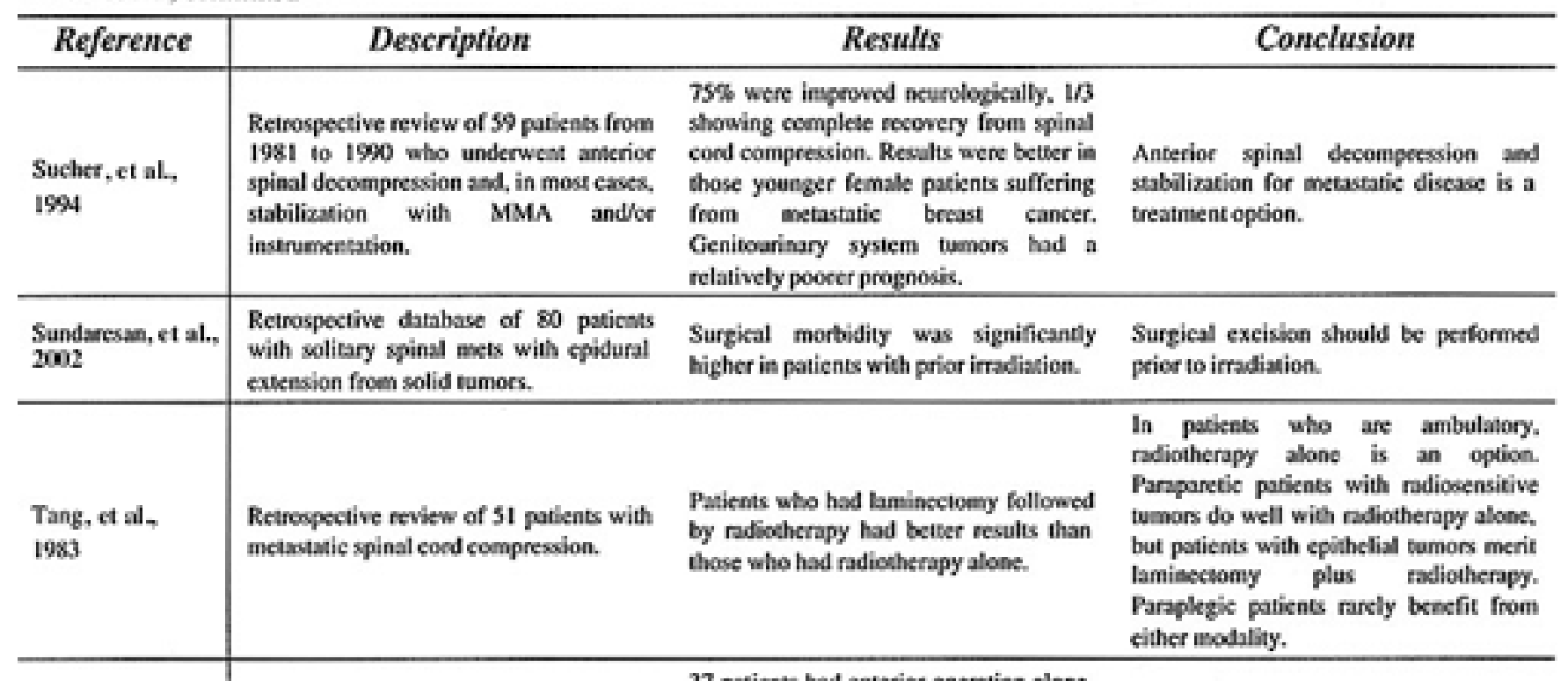

37 patients had anterior operation alonc, 4 had combined anutrioc and posterior decompressioe. $56 \%$ achieved major neurological recovery. 4 patients remained unchanged. 11 patients had minor improwensent. No potient with conplete paraplegia regained useful neurological recovery. Back pain was improved in $73 \%$ of patients.

$90 \%$ of patients had significant improvensent in pain after sargery. 12 of 16 patients who initially peesented in wheelchairs regained ambelatory function. 1-year cumulative survival was $60 \%$.

1994 to 1986 who underwent anterio Walsh, et al. 1997 resections of thoracic spine tumors.

Retrospective review of postoperative Weigel, et al., 1999 cetcome and quality of life in 86 surgical imerventions in 76 consecutive patients with symptomatic spinal metastases.

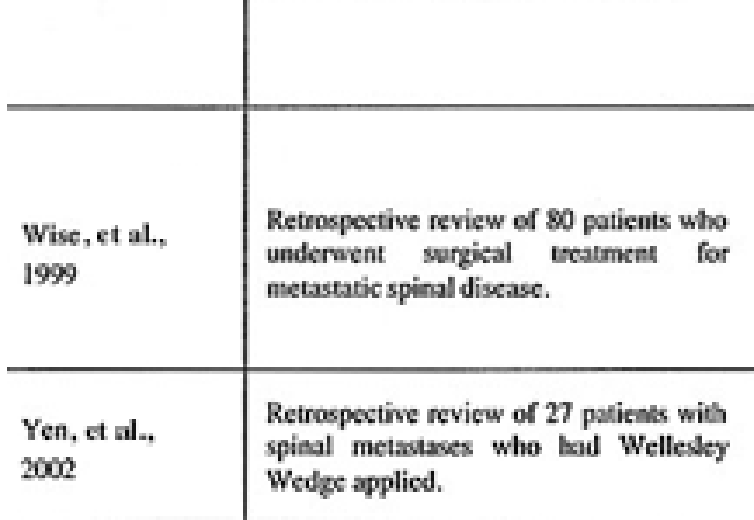

Posogerative mean survival was 13.1 montho, and mean time at boene after surgery was 11.1 months. Neurological improvensent in Frankel Score was seen in $58 \%$ of patients and $93 \%$ of potients were able to walk powogeratively. Pain relicf was noted in $89 \%$. $19 \%$ of surgical interventions were associated with complications and local tumer vecurrence developed in $22 \%$.

65 patients showed eo change in Frankel score, 19 improved one Frankel grade, and I deteriorated one Frankel grade. I paticas had paraplegia. 35 complications oceured in 20 paticnts, and 10 patients had multiple complications axcounting for 23 of the 35 postoperative peoblens.

$33 \%$ suffered medical complications, $22 \%$ had improved Frankel Score postoperatively, $92 \%$ maintained spinal stability throughout lifespan.
Anterior decompression is an option in the tetatment of malignant extradural tumors of the spine.

An stgressive surgical approach in cancer patients with locally advanced of metastaxic disease in the theracic spline was associaned with aeceptable morbidity and mortality. There was significant improvement in quality of life by controlliag intractable pain in $90 \%$ and recovery of ambulatory fanction in $75 \%$ of patients.

Amerioc decempressice is of benefft in most metastatic lesions in terms of satisfactory postoperative outcome and quality of life.

Most complications occursed in a small number of paticnts, indicating that carefal patient selection should be based on expected length of survival, we of radiation therapy. pessence of neurological deficit, and impending spinal instability or collapse caused by bone destruction.

Wellesley Wedge provides durable long uerm spinal stability in treating properly selecied paticnts with spinal mets. 
T. C. Ryken, et al.

TABLE 1, continued

Literature revew of studies of sungical management of vertebral column metastatic disease

Class III, continzed

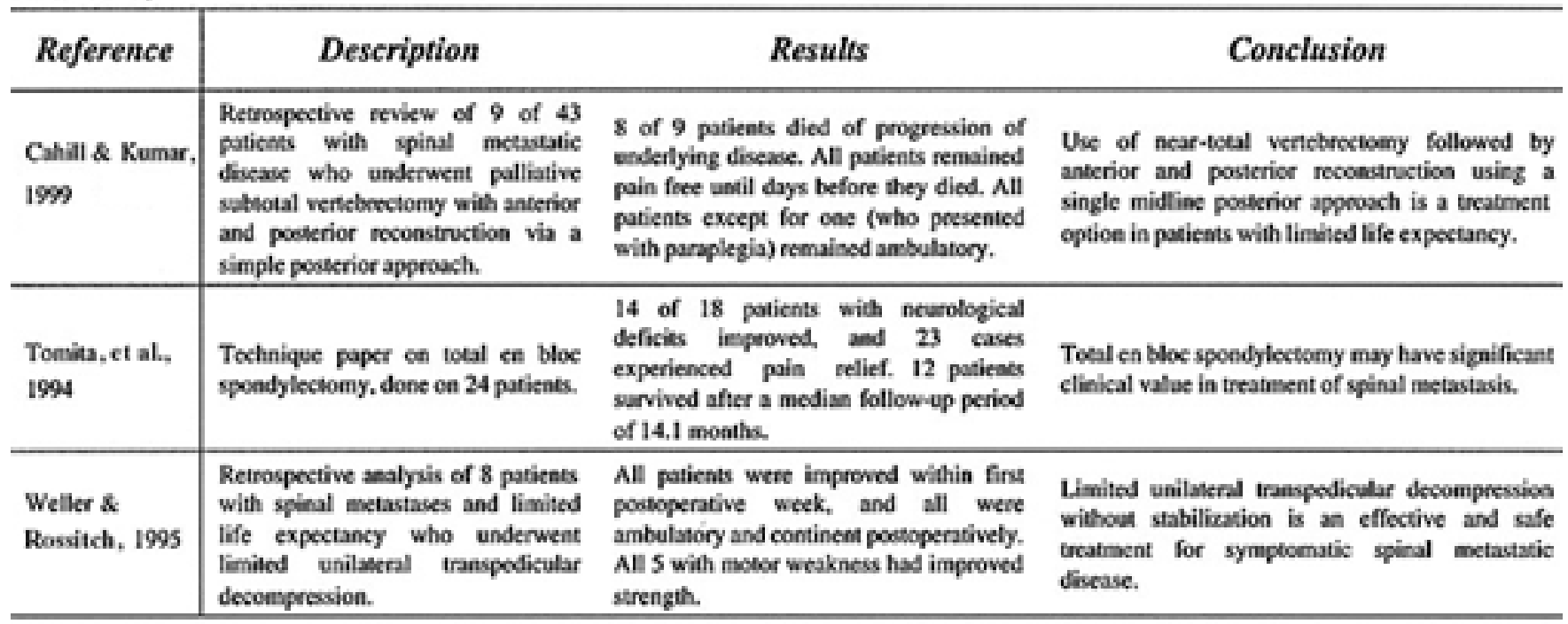

MMA = mothyl axthacrylate.

tastasis maintained ambulation. 6,8,17,24,25,27,29,38,41,51-55,63-65 In contrast, Arbit and Galicich ${ }^{5}$ performed a retrospective review of 10 patients who underwent anterior vertebral body resection and found little improvement in ambulatory function, but noted improvement in pain. In four studies, patients who presented with paraplegia or severe neurological dysfunction showed little or no improvement after surgery. ${ }^{10,48,58,61}$ DeWald, et al., ${ }^{17}$ found improvement in five of 11 patients presenting with paraplegia. In two studies, ${ }^{34,52}$ bladder continence improved in patients who underwent surgery.

In terms of survival, Sorensen, et al., ${ }^{53}$ showed that patients who underwent laminectomy followed by radiotherapy attained a longer survival duration; however, this may have reflected a milder stage of disease in these patients, which would improve the potential for survival. Chataigner and Onimus ${ }^{3}$ and Akeyson and McCutcheon ${ }^{14}$ showed that although pain and neurological function improved in patients who underwent surgery, survival did not change. At the time of this retrospective review, 93 of 107 patients were dead. Radiation treatment alone was advocated as a first-line therapy for patients with highly or moderately radiosensitive tumors ${ }^{50}$ and in those who were ambulatory; ${ }^{.5}$ although Tang, et al., showed that patients who underwent laminectomy followed by radiotherapy attained better results than those who underwent radiotherapy alone.

Outcome improved for patients who underwent surgery prior to radiation. ${ }^{6,22,38,57}$ Preoperative radiation increased the risk of wound complications and infection in two studies. ${ }^{22,57}$ Ghogawala, et al., found that the major wound complication rate was $32 \%$ in patients who underwent surgery after radiation, compared with $12 \%$ in patients in whom de novo surgery was performed. Sundaresan, et al., also found a $25 \%$ incidence of wound breakdown (10 of $40)$ in patients with prior radiation therapy compared with one wound infection in 40 in patients who underwent de novo surgery. One Class III study showed that the risk of major complications was significant, ${ }^{64}$ and McDonnell, et al., ${ }^{35}$ showed a major complication rate of $21 \%$ in patients who underwent anterior decompression and fusion; the majority of complications were related to pulmonary issues.

Several different approaches were used to ensure longterm stability for fusion, including the Wellesley wedge, ${ }^{49}$ anterior cervical plating, ${ }^{13}$ and anterior corpectomy. ${ }^{17} \mathrm{Su}-$

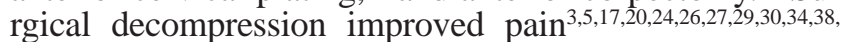
$41,52,61,63$ and the quality of life $\mathrm{e}^{13,14,24,63,64}$ in several studies. Nevertheless, three studies indicated that the patients' longevity should be taken into account when determining the indications for surgery. ${ }^{37,43,66}$

\section{DISCUSSION}

\section{Directions for Future Research}

Prospective, randomized clinical trials are needed to compare the outcome in patients treated with surgical intervention with the outcome in patients receiving radiotherapy as a first-line treatment. Additional large-cohort studies would add Class II evidence that would be valuable in assessing the role of surgical intervention. Other areas of interest include surgical methods, extent of tumor resection, and the role of multimodality therapies.

\section{Treatment Recommendations}

Standards. There is insufficient evidence to recommend a treatment standard.

Guidelines. Surgical decompression and stabilization in the face of spinal instability is recommended for patients who experience progressive neurological deficits without 
complete paraplegia, bowel or bladder dysfunction, or significant pain. The goal of surgical intervention should be to improve pain and/or the quality of life and may have no effect on the survival rate. We recommend that surgical decompression and fusion be considered with caution for patients who present with complete paraplegia, unless these procedures are required for diagnostic purposes.

Options. Radiotherapy should be considered as a treatment option for patients who present with complete paraplegia or paralysis related to spinal metastatic disease. Radiotherapy may also be considered as a treatment option for patients who are ambulatory, with minimal neurological deficit or pain, especially in patients who harbor a known, radiosensitive tumor. Patients who experience progressive neurological deficits despite receiving radiotherapy should be considered candidates for urgent surgical decompression and/or stabilization.

\section{CONCLUSIONS}

Surgical intervention for metastatic spinal disease is beneficial in that it alleviates pain caused by metastases and improves the patient's quality of life. Nonetheless, there has been insufficient evidence to show that surgical intervention will improve survival duration. Surgical decompression and fusion have been shown by a number of methods and approaches to produce spinal stability and maintain it for the remainder of the patient's life. Patients presenting with significant neurological deficits may experience marked improvement after surgical decompression and fusion, assuming that the individual does not present with complete paraplegia. There has been insufficient evidence to recommend surgical intervention routinely in patients who present with complete paraplegia. Radiotherapy without surgical intervention should be reserved for the following categories of patients: 1) those who have known, radiosensitive tumors; 2 ) those who have little or no pain or neurological deficit; or 3) as a palliative therapy in patients who present with paraplegia.

\section{References}

1. Aaron AD: The management of cancer metastatic to bone. JAMA 272:1206-1209, 1994

2. Abrams HL, Spiro R, Goldstein N: Metastases in carcinoma. Analysis of 1000 autopsied cases. Cancer 3:74-85, 1950

3. Akeyson EW, McCutcheon IE: Single-stage posterior vertebrectomy and replacement combined with posterior instrumentation for spinal metastasis. J Neurosurg 85:211-220, 1996

4. Anonymous: Methodology of guideline development. Neurosurgery 50 (Suppl 3):S5-S6, 2002

5. Arbit E, Galicich JH: Vertebral body reconstruction with a modified Harrington rod distraction system for stabilization of the spine affected with metastatic disease. J Neurosurg 83: 617-620, 1995

6. Bach F, Larsen BH, Rohde K, et al: Metastatic spinal cord compression. Occurrence, symptoms, clinical presentations and prognosis in 398 patients with spinal cord compression. Acta Neurochir 107:37-43, 1990

7. Barron KD, Hirano A, Araki S, et al: Experiences with metastatic neoplasms involving the spinal cord. Neurology 9:91-106, 1959

8. Bilsky MH, Boland PJ, Panageas KS, et al: Intralesional resection of primary and metastatic sarcoma involving the spine: out- come analysis of 59 patients. Neurosurgery 49:1277-1287, 2001

9. Black P, Nair S, Giannakopoulos G: Spinal epidural tumors, in Wilkins RH, Rengachary SS (eds): Neurosurgery, ed 2. New York: McGraw-Hill, 1996, Vol II, pp 1791-1804

10. Bruckman JE, Bloomer WD: Management of spinal cord compression. Semin Oncol 5:135-140, 1978

11. Byrne TN: Spinal cord compression from epidural metastases. N Engl J Med 327:614-619, 1992

12. Cahill DW, Kumar R: Palliative subtotal vertebrectomy with anterior and posterior reconstruction via a single posterior approach. J Neurosurg (Spine 1) 90:42-47, 1999

13. Caspar W, Pitzen T, Papavero L, et al: Anterior cervical plating for the treatment of neoplasms in the cervical vertebrae. $\mathbf{J}$ Neurosurg (Spine 1) 90:27-34, 1999

14. Chataigner H, Onimus M: Surgery in spinal metastasis without spinal cord compression: indications and strategy related to the risk of recurrence. Eur Spine J 9:523-527, 2000

15. Constans JP, de Divitiis E, Donzelli R, et al: Spinal metastases with neurological manifestations. Review of 600 cases. J Neurosurg 59:111-118, 1983

16. Delaney TF, Oldfield EH: Spinal cord compression, in DeVita VT Jr, Hellman S, Rosenberg SA (eds): Cancer: Principles and Practice of Oncology, ed 4. Philadelphia: JB Lippincott, 1993, pp 2118-2127

17. DeWald RL, Bridwell KH, Prodromas C, et al: Reconstructive spinal surgery as palliation for metastatic malignancies of the spine. Spine 10:21-26, 1985

18. Dunn RC Jr, Kelly WA, Wohns RN, et al: Spinal epidural neoplasia. A 15-year review of the results of surgical therapy. J Neurosurg 52:47-51, 1980

19. Durr HR, Wegener B, Krodel A, et al: Multiple myeloma: surgery of the spine: retrospective analysis of 27 patients. Spine 27:320-326, 2002

20. Fourney DR, Abi-Said D, Rhines LD, et al: Simultaneous anterior-posterior approach to the thoracic and lumbar spine for the radical resection of tumors followed by reconstruction and stabilization. J Neurosurg (Spine 2) 94:232-244, 2001

21. Gerszten PC, Ozhasoglu C, Burton SA, et al: Feasibility of frameless single-fraction stereotactic radiosurgery for spinal lesions. Neurosurg Focus 13 (4):Article 2, 2002

22. Ghogawala Z, Mansfield FL, Borges LF: Spinal radiation before surgical decompression adversely affects outcomes of surgery for symptomatic metastatic spinal cord compression. Spine 26:818-824, 2001

23. Gilbert RW, Kim JH, Posner JB: Epidural spinal cord compression from metastatic tumor: diagnosis and treatment. Ann Neurol 3:40-51, 1978

24. Gokaslan ZL, York JE, Walsh GL, et al: Transthoracic vertebrectomy for metastatic spinal tumors. J Neurosurg 89: 599-609, 1998

25. Hall AJ, Mackay NN: The results of laminectomy for compression of the cord or cauda equina by extradural malignant tumour. J Bone Joint Surg Br 55:497-505, 1973

26. Hammerberg KW: Surgical treatment of metastatic spine disease. Spine 17:1148-1153, 1992

27. Harrington KD: Anterior cord decompression and spinal stabilization for patients with metastatic lesions of the spine. J Neurosurg 61:107-117, 1984

28. Harrington KD: The use of methylmethacrylate for vertebralbody replacement and anterior stabilization of pathological fracture-dislocations of the spine due to metastatic malignant disease. J Bone Joint Surg Am 63:36-46, 1981

29. Hosono N, Yonenobu K, Fuji T, et al: Vertebral body replacement with a ceramic prosthesis for metastatic spinal tumors. Spine 20:2454-2462, 1995

30. Jackson RJ, Loh SC, Gokaslan ZL: Metastatic renal cell carcinoma of the spine: surgical treatment and results. J Neurosurg (Spine 1) 94:18-24, 2001 
31. Lee CK, Rosa R, Fernand R: Surgical treatment of tumors of the spine. Spine 11:201-208, 1986

32. Lenz M, Freid JR: Metastases to the skeleton, brain and spinal cord from cancer of the breast and the effect of radiotherapy. Ann Surg 93:278-293, 1931

33. Loblaw DA, Laperriere NJ: Emergency treatment of malignant extradural spinal cord compression: an evidence-based guideline. J Clin Oncol 16:1613-1624, 1998

34. Manabe S, Tateishi A, Abe M, et al: Surgical treatment of metastatic tumors of the spine. Spine 14:41-47, 1989

35. McDonnell MF, Glassman SD, Dimar JR II, et al: Perioperative complications of anterior procedures on the spine. J Bone Joint Surg Am 78:839-847, 1996

36. Moore AJ, Uttley D: Anterior decompression and stabilization of the spine in malignant disease. Neurosurgery 24:713-717, 1989

37. Nicholls PJ, Jarecky TW: The value of posterior decompression by laminectomy for malignant tumors of the spine. Clin Orthop:210-213, 1985

38. Onimus M, Schraub S, Bertin D, et al: Surgical treatment of vertebral metastasis. Spine 11:883-891, 1986

39. O'Rourke T, George CB, Redmond J III, et al: Spinal computed tomography and computed tomographic metrizamide myelography in the early diagnosis of metastatic disease. J Clin Oncol 4:576-583, 1986

40. Patchell R, Tibbs PA, Regine WF, et al: A randomized trial of direct decompressive surgical resection in the treatment of spinal cord compression caused by metastasis. Proc Am Soc Clin Oncol 22:1, 2003 (Abstract)

41. Perrin RG, McBroom RJ: Anterior versus posterior decompression for symptomatic spinal metastasis. Can J Neurol Sci 14: 75-80, 1987

42. Posner JB: Management of central nervous system metastases. Semin Oncol 4:81-91, 1977

43. Preciado DA, Sebring LA, Adams GL: Treatment of patients with spinal metastases from head and neck neoplasms. Arch Otolaryngol Head Neck Surg 128:539-543, 2002

44. Ratanatharathorn V, Powers WE: Epidural spinal cord compression from metastatic tumor: diagnosis and guidelines for management. Cancer Treat Rev 18:55-71, 1991

45. Ruff RL, Lanska DJ: Epidural metastases in prospectively evaluated veterans with cancer and back pain. Cancer 63: 2234-2241, 1989

46. Ryken TC, Meeks SL, Traynelis V, et al: Ultrasonographic guidance for spinal extracranial radiosurgery: technique and applicaiton for metastatic spinal lesions. Neurosurg Focus 11 (6): Article 8, 2001

47. Schaberg J, Gainor BJ: A profile of metastatic carcinoma of the spine. Spine 10:19-20, 1985

48. Schoeggl A, Reddy M, Matula C: Neurological outcome following laminectomy in spinal metastases. Spinal Cord 40: 363-366, 2002

49. Sekhar KR, Spitz DR, Harris S, et al: Redox-sensitive interaction between KIAA0132 and Nrf2 mediates indomethacin-induced expression of gamma-glutamylcysteine synthetase. Free Radic Biol Med 32:650-662, 2002

50. Siegal T, Siegal T: Current considerations in the management of neoplastic spinal cord compression. Spine 14:223-228, 1989

51. Siegal T, Siegal T: Surgical decompression of anterior and posterior malignant epidural tumors compressing the spinal cord: a prospective study. Neurosurgery 17:424-432, 1985

52. Siegal T, Tiqva P, Siegal T: Vertebral body resection for epidu- ral compression by malignant tumors. Results of forty-seven consecutive operative procedures. J Bone Joint Surg Am 67: 375-382, 1985

53. Sorensen S, Borgesen SE, Rohde K, et al: Metastatic epidural spinal cord compression. Results of treatment and survival. Cancer 65:1502-1508, 1990

54. Sucher E, Margulies JY, Floman Y, et al: Prognostic factors in anterior decompression for metastatic cord compression. An analysis of results. Eur Spine J 3:70-75, 1994

55. Sundaresan N, Digiacinto GV, Hughes JE, et al: Treatment of neoplastic spinal cord compression: results of a prospective study. Neurosurgery 29:645-650, 1991

56. Sundaresan N, Krol G, DiGiacinto GV, et al: Metastatic tumors of the spine, in Sundaresan N, Schmidek HH, Schiller AL, et al (eds): Tumors of the Spine: Diagnosis and Clinical Management. Philadelphia: WB Saunders, 1990, pp 279-304

57. Sundaresan N, Rothman A, Manhart K, et al: Surgery for solitary metastases of the spine: rationale and results of treatment. Spine 27:1802-1806, 2002

58. Tang SG, Byfield JE, Sharp TR, et al: Prognostic factors in the management of metastatic epidural spinal cord compression. J Neurooncol 1:21-28, 1983

59. Tomita K, Kawahara N, Kobayashi T, et al: Surgical strategy for spinal metastases. Spine 26:298-306, 2001

60. Tomita K, Toribatake Y, Kawahara N, et al: Total en bloc spondylectomy and circumspinal decompression for solitary spinal metastasis. Paraplegia 32:36-46, 1994

61. Turner PL, Prince HG, Webb JK, et al: Surgery for malignant extradural tumours of the spine. J Bone Joint Surg Br 70: 451-455, 1988

62. Wai EK, Finkelstein JA, Tangente RP, et al: Quality of life in surgical treatment of metastatic spine disease. Spine 28: 508-512, 2003

63. Walsh GL, Gokaslan ZL, McCutcheon IE, et al: Anterior approaches to the thoracic spine in patients with cancer: indications and results. Ann Thorac Surg 64:1611-1618, 1997

64. Weigel B, Maghsudi M, Neumann C, et al: Surgical management of symptomatic spinal metastases. Postoperative outcome and quality of life. Spine 24:2240-2246, 1999

65. Weller SJ, Rossitch E Jr: Unilateral posterolateral decompression without stabilization for neurological palliation of symptomatic spinal metastasis in debilitated patients. J Neurosurg 82:739-744, 1995

66. Wise JJ, Fischgrund JS, Herkowitz HN, et al: Complication, survival rates, and risk factors of surgery for metastatic disease of the spine. Spine 24:1943-1951, 1999

67. Wong DA, Fornasier VL, MacNab I: Spinal metastases: the obvious, the occult, and the impostors. Spine 15:1-4, 1990

68. Yen D, Kuriachan V, Yach J, et al: Long-term outcome of anterior decompression and spinal fixation after placement of the Wellesley Wedge for thoracic and lumbar spinal metastasis. J Neurosurg (Spine 1) 96:6-9, 2002

69. Young RF, Post EM, King GA: Treatment of spinal epidural metastases. Randomized prospective comparison of laminectomy and radiotherapy. J Neurosurg 53:741-748, 1980

Manuscript received September 15, 2003

Accepted in final form October 10, 2003.

Address reprint requests to: Timothy Ryken, M.D., Department of Neurosurgery, 1849 John Pappajohn Pavilion, 200 Hawkins Drive, Iowa City, Iowa 52242. email: timothy-ryken@uiowa.edu. 